\title{
Follower psychological need satisfaction as a mediator between leader and follower use of emotions and follower job performance
}

\author{
Sunu Widianto and Celeste P.M. Wilderom
}

\begin{abstract}
Purpose - The purpose of this paper is to test whether follower psychological need satisfaction, a key variable in the self-determination theory (SDT), mediates between both follower and leader use of emotions and follower job performance.

Design/methodology/approach - The authors surveyed health-care professionals who were employed by various organizations, and at the same time, were enrolled in a bachelor and part-time MSc program at an Indonesian university $(N=220)$. Structural equation modeling was used to test the two hypothesized mediation effects.

Findings - The results show that to get high follower job performance, both leaders and followers must be proficient in using their own emotions in constructive ways. Both significant associations were mediated by follower psychological need satisfaction. In addition, follower use of emotions was also directly related to follower job performance, indicating partial mediation.

Originality/value - By examining the emotional intelligence dimension "use of emotions" by both followers and their leaders, and by pointing to the importance of the constructive use of their emotions at work, the authors extend the SDT. Two probable affective mechanisms, which precede the job performance effects of satisfying followers' psychological needs, were identified from the results.
\end{abstract}

Keywords Psychological need satisfaction, Follower job performance, Use of own emotions, Emotional intelligence

Paper type Research paper

\section{Introduction}

Over the past decade, the topic of emotions and emotional intelligence (EI) in organizations has received increasing attention (Ashkanasy et al., 2017; Ashkanasy and Humphrey, 2011). There is evidence, for instance, that leader El contributes to a unit's objective work performance (Wilderom et al., 2015), and followers' own emotions can also play a performative role at work (Ashkanasy et al., 2017). Previous empirical field studies on emotions at work have focused mostly on leader emotions (Antonakis et al., 2009; Ashkanasy et al., 2017; Ashkanasy and Humphrey, 2011; Gooty et al., 2010; Van Knippenberg et al., 2008). A study by Venus et al. (2013) shows that leaders who make good use of their own emotions can influence their followers' feelings and behaviors in a very effective way. In the present study, we assume that both followers' and a leader's use of emotions influence follower job motivation and performance. Damen et al. (2008) already demonstrated that when there is a match between a leader's emotional display and followers' positive affect, the link between leader emotional display and follower
Sunu Widianto is based at the Department of Management and Business, Faculty of Economics and Business, Padjadjaran University, Bandung, Indonesia. Celeste P.M. Wilderom is based at the Department of Change Management and Organizational Behavior, University of Twente, Enschede, The Netherlands.

Received 3 May 2020 Revised 28 November 2020 29 March 2021 Accepted 10 April 2021

This research is funded by Indonesian Ministry of Education, Culture, Research \& Technology. 
performance becomes moderated. Other literature on how follower perceptions of their leader's emotions evoke follower reactions and performance is still sparse (Gooty et al., 2010; Montano et al., 2017).

While examining how leader and follower emotions underpin follower job motivation and performance, we focus in this study on how followers' and leaders' use of emotions relates to follower satisfaction with the three well-known basic follower needs, as described in the self-determination theory (Ryan and Deci, 2000), and through that, to follower job performance. According to the self-determination theory, there are three innate or intrinsic human needs:

1. need for autonomy;

2. need for competence; and

3. need for relatedness.

Vandercammen et al. (2014a) described these needs as follows. The need for autonomy pertains to people's need to satisfy their own interests, i.e. to choose freely and initiate their own behavior; this type of need is met when followers are free to choose how to perform a task. The need for competence focuses on how people feel regarding being capable and effective; performing a challenging task can lead to this need being met. Finally, the relatedness need refers to establishing mutual respect, feeling connected to and accepted by others. At work, pleasant relationships with both peers and leaders will fulfil this third type of intrinsic need.

Despite the many studies worldwide showing that satisfying these three basic motivational needs influences follower job performance (Cerasoli et al., 2016), few have investigated their antecedent emotional mechanisms. Moreover, the self-determination theory (SDT) has practically neglected such types of mechanisms. One reason for the lack of SDT studies on the effects of emotions might be that emotions are assumed to play a distal role in this frame (Vandercammen et al., 2014a); Conventionally, emotion or affect are not part of motivationgenerative mechanisms (Vandercammen et al., 2014b). Studies guided by the SDT have mainly focused on emotion as a consequence of either need satisfaction or motivation, but not as a moving factor (Vandercammen et al., 2014a). To enrich the SDT theory, the present study investigated how high follower need satisfaction and job performance are linked to follower use of own emotions and the leader's use of emotions as perceived by the follower (Figure 1).

We demonstrate that both affective types of follower perceptions act as a source of information for the follower with which he or she underpins his or her motivation to perform well in his/her job. Moreover, we show that the SDT, which originated in the west, can also help in understanding the Asian work context better. This is because we performed our research in Asian health care, one of the few major growth sectors where older and newer ways of dealing with the manifold pressures at work, including shifting employee performance standards, are currently playing out (Kumar, 2019). While most emotion and psychological need satisfaction studies have been conducted in western contexts, we present here an empirical field study carried out in a non-western country. Western values, like independence and assertiveness, can motivate people to express their emotions, whereas Asian values, like togetherness and harmonious relationships, can urge people to hide their emotions (Suharnomo and Hashim, 2019). Despite this cross-cultural difference, we will show that Asian employees' perceptions of the use of emotions still plays a performative role. Furthermore, many El studies have pointed to the fact that the individual components of the overall El construct merit further scrutiny (Huang et al., 2019; Extremera et al., 2018). Our study can be seen as a response to this need to understand the El subdimensions better. Given the central importance of use of emotion to the El construct, we conceptualize this variable as one of the affective antecedents of psychological need 


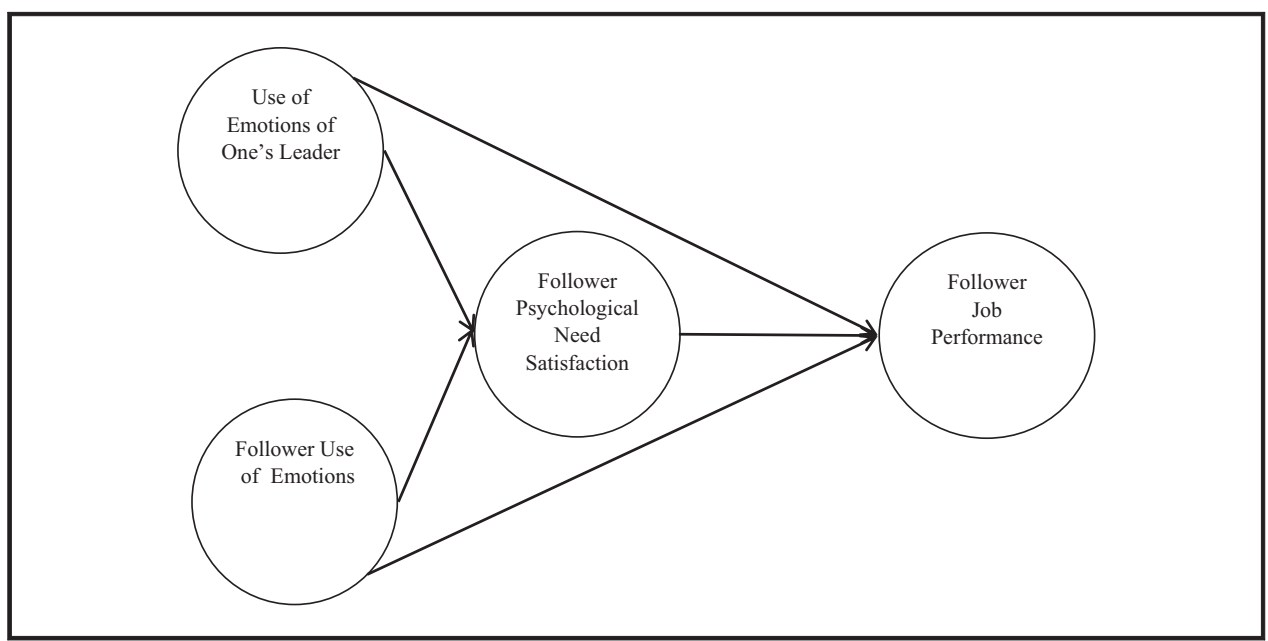

satisfaction, and we link it to the SDT, which, as a theory, is mostly cognitive in nature. Linking follower psychological need satisfaction here to the emotional spectrum of a follower requires some theoretical integration, as we are essentially exploring how employees can satisfy their three core psychological needs in the context of their workplace's need for high performance.

\section{Theory and hypotheses}

Mayer and Salovey (1997) proposed that El comprises the ability to perceive, understand, regulate and use emotions. Many studies have focused on general $\mathrm{EI}$, or on the regulation and perception of one's own emotions and those of others; very few on "the use of emotions." Yet, this particular use dimension is quite vital, and even quite central in the following well-known definition of El: "the ability to carry out accurate reasoning about emotions and the ability to use emotions and emotional knowledge to enhance thought" (Mayer et al., 2008, p. 511). Hence, one may see the "use of emotions" as a form of social information processing at work. This is because "use of emotion" refers to how people use their emotions to increase their own confidence and motivation to put a high degree of personal effort into goal achievement (Salovey and Mayer, 1990). Similarly, Mayer and Salovey (1997) defined "use of emotion" as the self-perceived tendency to motivate oneself to improve performance. Individuals who are very capable of using their own emotions seem to be able to motivate themselves better (Law et al., 2004).

Channeling one's emotions is a fairly complex self-informational process requiring flexible planning, creative thinking, redirected attention and motivation to achieve particular goals (Salovey and Mayer, 1990; Busari et al., 2019), which also requires positive emotions (Fredrickson, 2001). People who can channel their emotions well will move in positive or productive/constructive directions (Fredrickson and Losada, 2005) because positive emotions are also needed for human flourishing (Fredrickson, 2001), which is characterized by the satisfaction of individual needs (Fredrickson and Losada, 2005). The growing body of literature on emotions as information has revealed some mechanisms by which people can also respond to the emotions of others (Van Doorn et al., 2015; Alam and Ahmad, 2018). The social information theory (Van Kleef, 2009; Van Kleef et al., 2010, 2011, p. 118) postulates that "just as emotions provide information to the self [...], emotional expressions provide information to observers, which may influence their cognitions, attitudes, and behaviour." Hence, emotional expressions at work can be based on others' emotions such 
as those emanating from the leader (De Melo et al., 2014). In terms of affect as information, leaders' affect can convey explicit information to followers, while emotional contagion is an implicit process to produce emotions in followers (Sy et al., 2018). In addition to the information provided by a follower's own emotions (Vandercammen et al., 2014a), which can be seen as the basis for follower judgment (Gasper and Clore, 2000; Spering et al., 2005), followers are expected to use significant others' emotions, like their leaders' emotions, as a source of relevant information at work (Petty and Briñol, 2015). Followers' processing of their own emotions and those of their leaders occurs while trying to understand ambiguous social situations and to grasp and coordinate their social life better (Van Kleef, 2009; Van Doorn et al., 2015), which help workers to meet their own needs.

This theorizing can be linked to the SDT because, when people try to channel experienced emotions in a constructive direction, they will probably want to satisfy their intrinsic needs:

- need for autonomy;

- need for competence; and

- need for relatedness (Deci and Ryan, 1985).

Satisfying these three needs will facilitate self-motivation, which is similar to intrinsic motivation. Intrinsic or psychological need satisfaction is the element of job satisfaction that is positively related to job performance. Therefore, employees who experience that their intrinsic needs have been met will have strong intrinsic work motivation and will therefore be able to achieve high job performance. The current study will integrate these three needs from the SDT and link them to a key element of El: to shed light on the effects of both leader and follower use of their own emotions on follower job performance. Gooty et al. (2010), among others, suggested that both leaders' and followers' ability to manage their range of emotions at work is critical to organizations. Therefore, we propose that when followers see that both their leader and they themselves can use their own emotions in constructive ways, follower job performance will improve. We postulate in the next section that this occurs through follower need satisfaction.

\section{Perceived leader use of emotions, follower need satisfaction and job performance}

In the leadership process, leader emotions are well-known key sources for follower emotions (Fisk and Friesen, 2012; Silard and Dasborough, 2021). This means that emotions (and even moods) are transferred from leaders to followers (Kelly and Barsade, 2001). Followers see their leaders as a source of either encouragement or discouragement (Newcombe and Ashkanasy, 2002). Emotional leader expressions also appear to work through emotional contagion. According to the emotional contagion principle (Hatfield et al., 1994), leaders transmit emotions to their followers during social interaction. As leaders' positions come with power in the organizational hierarchy, their use of emotions reinforces how followers think about their own performance at work (Sy and Choi, 2013). Leaders who are highly enthusiastic and positively energetic are more likely to create or maintain a positive emotional environment for their followers, which in turn helps followers to thrive (Barsade, 2002; Haver et al., 2013). Thus, leaders who can convey and display positive emotions effectively to their followers are often seen as effective leaders or at least as influencing follower behavior positively (Connelly and Ruark, 2010). Followers' frequent exposure to positive leader emotions will build followers' reservoirs of positive resources to perform well and to improve their well-being (Tugade and Fredrickson, 2007). Positive affect is assumed to broaden one's thought-action repertoire, enhance one's creativity and ability to come up with ideas as well as one's interpersonal relationships, which can then help build follower resources. Higher follower well-being may, thus, lead to better follower performance by increasing one's resources and stimulating creative efforts at goal achievement (Fredrickson, 2001). 
Similarly, leaders who display negative feelings or emotions will negatively influence their followers (Newcombe and Ashkanasy, 2002; Sy et al., 2005). Reacting negatively, nonconstructively or irrationally when faced with challenges at work is more likely to foster frustration or dissatisfaction among followers, which, in turn, creates a negative organizational performance climate (Dasborough, 2006). Leaders' frequent negative emotions come at the expense of followers' confidence, which could lead to less effort on the part of the followers to perform tasks (Connelly and Ruark, 2010). Conversely, when a leader uses his or her emotions constructively, he or she is more likely to demonstrate positivity to the followers, thereby generating followers' motivation to achieve the desired goals (Hatfield et al., 1994; Shamir et al., 1993). Also, some studies at the individual level have shown that people in organizations will perform at a higher level when they experience positive emotions, but not when they experience negative emotions (Barsade et al., 2000; Bauer and Green, 1996). A study of a large company designing and manufacturing hightech products investigated the effects of satisfying the three psychological needs on job performance (Chiniara and Bentein, 2016). It showed that follower psychological need satisfaction mediates the relationship between servant leadership and job performance. Servant leadership is known to provide followers with emotional support, feedback or resources and is, therefore, conceptually related to a leader's use of emotions. That study's outcome is consistent with the results of a simulation study in which a leader's positive affect was strongly associated with follower intrinsic motivation (Kraiger et al., 1989; Pattnaik and Panda, 2020).

Jõesaar et al. (2012) indicated that followers' need satisfaction mediates the relationship between peer-created motivational climate and intrinsic motivation. Basic need satisfaction also mediates between the work environment and employee's received support in both paid and unpaid work contexts (Gillet et al., 2012; Van den Broeck et al., 2008; Gagne, 2003; Haivas et al., 2012). Accordingly, if peer support at work is an important factor for employee intrinsic motivation, it is plausible that a leader's ability to use emotions effectively will also benefit follower growth and performance (Chiniara and Bentein, 2016). When leaders provide positive feedback based on their genuine emotions, they are likely to increase followers' sense of competence and confidence (Damen et al., 2008). This type of information can act as an important job resource that will, in turn, inspire followers to achieve higher job performance (Damen et al., 2008):

H1. Follower psychological need satisfaction mediates the relationship between a leader's use of emotions and follower job performance.

\section{Follower use of emotion, follower need satisfaction and job performance}

We suggest that not only a leader's ability to use positive emotions, but also a follower's constructive use of own emotions can affect follower fulfillment of their three basic intrinsic needs. People's current experiences of good and bad feelings are associated with flourishing (Fredrickson, 2001). Positive emotions can enhance flourishing or well-being. In addition, "experiencing positive emotions opens and broadens minds - people become more open to others and see more action possibilities - and builds intellectual, relational, and psychological resources" (Verleysen et al., 2014, p. 6). This idea is supported by the empirical finding, based on diaries, that followers' own positive and negative emotions can significantly influence psychological need satisfaction (Vandercammen et al., 2014a).

Several other studies have already shown that the fulfilment of employees' basic intrinsic needs at work is positively related to their job performance (Baard et al., 2004; Gagne and Deci, 2005). Van den Broeck et al. (2008) found that satisfaction with the three basic psychological needs mediates the relationship between job demands and resources on the one hand, and emotional exhaustion and vigor on the other. The Leroy et al. (2015) survey, administered in small- to medium-sized businesses, revealed that followers' satisfaction with their three basic intrinsic needs was significantly associated with follower performance. 
Recent work with the SDT shows that all emotional experiences, be it pleasant or unpleasant, provide information that can affect people's degree of psychological health or thriving (Benita et al., 2020; Deci and Ryan, 2000). Likewise, when followers are voluntarily able to process their own emotion as important information, it may give them a sense of understanding their own emotions, which will help them to feel more competent and autonomous, also in social relationships (Benita et al., 2020). Hence, when followers are in the habit of making constructive use of their own emotions, it is related to their degree of satisfaction with their basic psychological needs, i.e. feeling more satisfied about their degree of autonomy and competence in using their emotions (Roth et al., 2018), and having better-quality relationships (Benita et al., 2017). Thus, we suggest here that when followers are able to use their own emotions in constructive ways, they will feel more competent and self-confident to cope with stressful social-emotional situations at work, which will positively affect their level of job performance. Hence:

H2. Follower psychological need satisfaction mediates the relationship between follower use of emotions and follower job performance.

\section{Methods}

A pilot study preceded the main, cross-sectional survey study. The original English questionnaire was translated into Indonesian (Bahasa) using the back-translation method. The face validity of the survey scales was tested on seven nurses and a pharmacist who met the inclusion criteria for participants, i.e. they had to be university graduates of nursing or pharmacy schools (Anderson and Gerbing, 1991). We used Anderson and Gerbings's (1991) item-sort task; almost all the items were sorted properly. Some items were thus modified slightly to suit the health-care context in Indonesia.

The main study involved 220 health-care employees who were students at the nursing and pharmacy schools of a large university in Bandung, Indonesia. Prior to distributing the questionnaire, we contacted the program director of the graduate schools for permission to collect data from their current graduate students. The students participating in this study worked part-time in a variety of environments, such as hospitals, universities, pharmaceutical companies and drug stores. These respondents were, thus, selected on the basis of convenience sampling. All the respondents were informed that their participation was voluntary and confidential, and that their data would only be used for academic research. The mean age of the respondents was 28.9 years $(S D=4.75)$, and their mean work experience in their current positions was 3.2 years $(S D=1.84)$. The sample consisted of $67.7 \%$ women.

\section{Measures}

Leaders' and followers' use of emotion. Use of emotion was measured with a four-item scale (Wong and Law, 2002). It has strong test-retest reliability as well as strong construct and discriminant validity (Law et al., 2008, 2004; Shi and Wang, 2007). The followers were asked to rate their perception of the use of emotions by their leaders and by themselves on this scale. Item examples are: "My supervisor always tells him- or her-self that he or she is a competent person" and "I always tell myself that I am a competent person," for leader- and self-ratings, respectively. Responses were based on a seven-point Likert scale, ranging from 1 (strongly disagree) to 7 (strongly agree). Cronbach's $\alpha$ values of use of emotions by leaders and followers were 0.90 and 0.77 , respectively.

Follower psychological need satisfaction. To measure psychological need satisfaction, we used the often used ten-item scale (Deci et al., 2001). Participants were asked to indicate to what extent they agreed with the statements about satisfying the three types of need. Their responses were also collected using seven-point Likert scales, ranging from 1 (poor) to 7 (excellent). The subscale "Satisfaction of Autonomy Needs" consists of three items. A 
sample item is "I am free to express my ideas and opinions on the job." The subscale "Satisfaction of Competence Needs" has three items, e.g. "I have been able to learn interesting new skills in my job." The subscale "Satisfaction of Relatedness Needs" consists of four items. A sample item is "I really like the people I work with." We conducted a factor analysis with principal component analysis (PCA, promax rotation) to test the validity of the ten-items scale. The results showed one factor had an eigenvalue above 1 and each item loaded highest on the intended factor. Cronbach's $\alpha$ of the total scale was 0.87 .

Follower job performance. We measured follower job performance with Williams and Anderson's (1991) well-established instrument consisting of four items. A sample item is "I complete assigned duties adequately." The responses were again based on a seven-point Likert scales, ranging from 1 (strongly disagree) to 7 (strongly agree). Cronbach's $\alpha$ was 0.92 .

\section{Control variables}

We included gender, age and education as control variables. Previous studies found significant correlations between gender and age and the degree of satisfaction of the three basic needs (Gómez-Baya et al., 2018; Kovjanic et al., 2012). The demographic profile of this study's respondents is shown in Table 1.

\section{Analyses}

We performed a confirmatory factor analysis with AMOS 22 to evaluate the measurement model of the focal variables: follower's perception of leader's and own emotions, follower psychological need satisfaction and follower job performance, i.e. to test if the measurements were distinct. The results showed that the expected four-factor model had a good fit with the data: $\chi^{2}=293.90, d f=197, p<0.000 ; \mathrm{CFI}=0.96$; RMSEA $=0.05$; $\mathrm{SRMR}=0.05$ (Hu and Bentler, 1999).

The two hypothesized mediations were tested by using Baron and Kenny's (1986) three conditions for mediation (Mathieu and Taylor, 2006). According to these authors, a mediation is present when:

- there is a significant relationship between the independent and the dependent variable;

- a significant relationship exists between the independent variable and the mediator; and

- a significant relationship exists between the mediator and the dependent variable while holding the independent variable constant.

There is a full mediating effect if the independent variable does not have a significant relationship with the dependent variable when the mediator is added to the regression.

\section{Table 1 The respondents' profile}

\begin{tabular}{lll} 
Characteristics & Profile & (\%) \\
\hline Gender & Male & 29.5 \\
Age & Female & 67.3 \\
& $20-25$ & 17 \\
& $26-30$ & 28 \\
& $31-35$ & 28 \\
Highest educational degree & $36-40$ & 19 \\
& More than 40 & 7 \\
& Vocational degree & 34.5 \\
& University bachelor & 62.8
\end{tabular}


To reduce the common method bias inherent to our research design, we followed Podsakoff et al. (2003): participation in the survey was on a voluntary basis; confidentiality of the respondents' data was assured; a guarantee was given that their individual data would only be used for academic purposes; a guarantee of anonymity was also given. In addition, the respondents were assured that their data would always be reported as aggregate scores (Pattnaik and Panda, 2020). An additional test was used to check for this possible bias: Harman's (1976) single-factor test examined whether a single factor, based on a factor analysis with all items, would explain more than $50 \%$ of the variance. That would indicate a serious common method problem. However, this was not the case here; it explained $30 \%$ of the variance.

\section{Results}

Table 2 presents the means, standard deviations, internal consistencies and correlations of all of the variables in this study. The internal consistencies of the scales were all higher than 0.70 , ranging from 0.77 to 0.92 , showing that the scales for the use of emotion (by leaders and followers), psychological need satisfaction and job performance were reliable measurements in the work settings in which they were applied. Use of emotion by the leaders was significantly related to follower psychological need satisfaction $(r=0.39, p<$ 0.01 ), and use of emotion by the followers was also significantly related to their psychological need satisfaction $(r=0.45, p<0.01)$. Follower psychological need satisfaction was related to follower job performance $(r=0.54, p<0.01)$. These results are consistent with $\mathrm{H} 1$ and $\mathrm{H} 2$.

\section{Testing the hypotheses}

While testing our model, we controlled for the common latent factor (Engelen et al., 2015). The results indicated that the hypothesized model fits the data and meets the fit criteria $\left(\chi^{2}=1.840 d f=199, p<0.001, \mathrm{CFI}=0.94\right.$, RMSEA $\left.=0.06\right)$. The standardized path coefficients presented in Figure 2 show that use of the leader's emotion by the follower was significantly related to follower psychological need satisfaction $(\beta=0.28, p<0.01)$, which in turn was related to follower job performance (controlled for by the independent variables) $(\beta=0.63, p<0.01)$. Thus, $H 1$ is supported. The findings also show that the direct relationship between use of emotion by the leader and follower job performance was not significant $(\beta=0.17, n s)$, indicating full mediation.

Furthermore, follower use of emotions was significantly related to follower psychological need satisfaction $(\beta=0.62, p<0.01$ ), which in turn was significantly associated with

\section{Table 2 Means, standard deviations, bivariate correlations and internal consistency coefficients}

\begin{tabular}{|c|c|c|c|c|c|c|c|c|c|c|}
\hline Variables & $M(S D)$ & 1 & 2 & 3 & 4 & 5 & 6 & 7 & 8 & 9 \\
\hline \multicolumn{11}{|l|}{ Focal variables } \\
\hline 1. Use of emotions of one's leader & $5.60(1.13)$ & 0.90 & & & & & & & & \\
\hline 2. Follower use of emotions & $5.70(0.80)$ & $0.16^{*}$ & 0.77 & & & & & & & \\
\hline 3. Autonomy & $5.78(0.78)$ & $0.33^{* *}$ & $0.48^{* *}$ & 0.63 & & & & & & \\
\hline 4. Competence & $5.59(0.87)$ & $0.35^{* *}$ & $0.42^{* *}$ & $0.71^{* *}$ & 0.70 & & & & & \\
\hline 5. Relatedness & $4.00(0.63)$ & 0.11 & 0.04 & 0.05 & $0.16^{*}$ & 0.77 & & & & \\
\hline 6. Follower psychological need satisfaction & $5.01(0.55)$ & $0.36^{* *}$ & $0.43^{* *}$ & $0.79^{* *}$ & $0.85^{* *}$ & $0.55^{* *}$ & 0.87 & & & \\
\hline 7. Follower job performance & $5.83(0.72)$ & $0.28^{* *}$ & $0.49^{* *}$ & $0.62^{* *}$ & $0.54^{* *}$ & 0.04 & $0.55^{* *}$ & 0.92 & & \\
\hline \multicolumn{11}{|l|}{ Control variables } \\
\hline 8. Gender & & -0.03 & -0.02 & -0.04 & -0.04 & 0.09 & 0.00 & -1.29 & & \\
\hline 9. Age & $31.1(6.88)$ & 0.00 & 0.03 & -0.05 & -0.06 & 0.02 & -0.04 & -0.08 & -0.05 & \\
\hline 10. Education & $1.00(0.05)$ & 0.07 & 0.09 & 0.02 & 0.03 & 0.03 & 0.04 & 0.06 & 0.05 & -0.02 \\
\hline
\end{tabular}




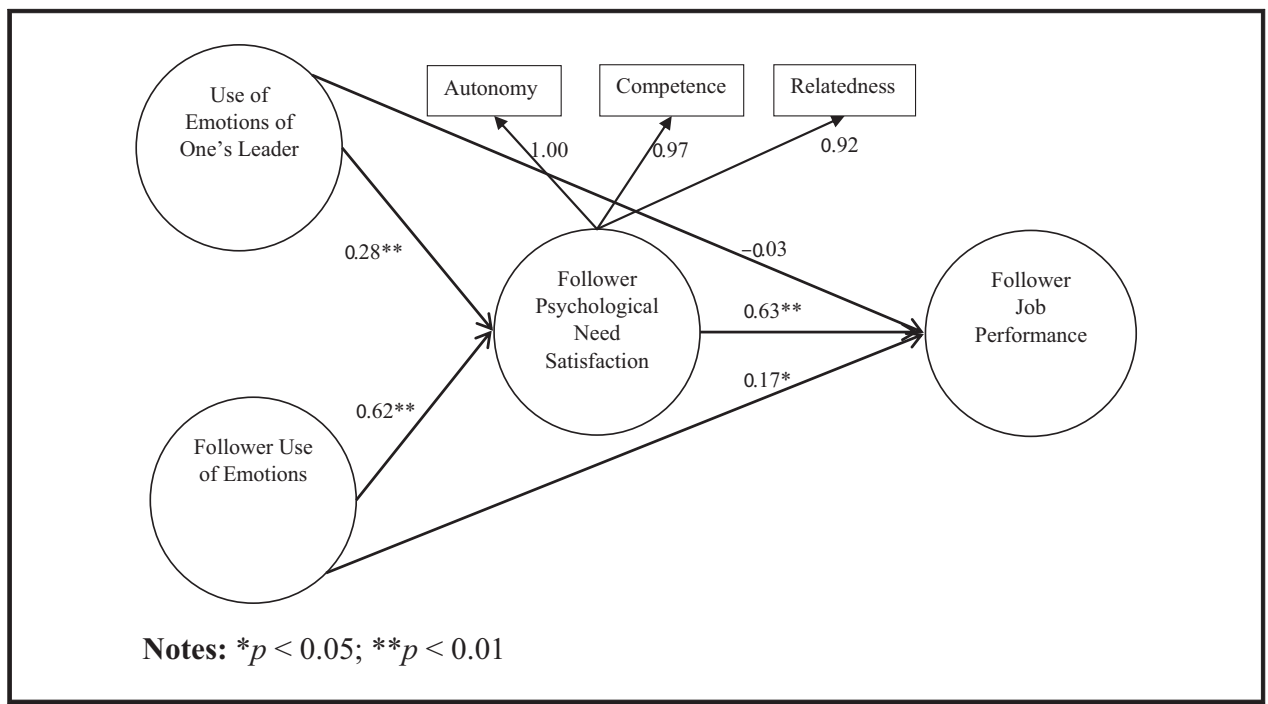

follower job performance (controlled for by the independent variables) $(\beta=0.63, p<0.01$ ). However, follower use of emotions was also directly related to their job performance ( $\beta=$ $0.17, p<0.05)$, indicating partial mediation.

We then calculated the indirect mediating effects of both leader and follower use of emotions on follower job performance, and the results were significant $(\beta=0.18, p<0.05$ and $\beta=0.40, p<0.01$, respectively). Thus, the relationship between use of emotions by both the leaders and followers, and follower job performance, was mediated by follower psychological need satisfaction, which supported both $\mathrm{H} 1$ and $H 2$. As the model contains a common latent factor, the results represent a conservative test of these hypotheses.

\section{Discussion}

The present study examines the relationship between both leader and follower's use of emotions and follower job performance. It tests whether follower psychological need satisfaction mediates both linkages. As hypothesized, follower psychological need satisfaction mediates the relationship between a leader's use of own emotions and follower job performance. Follower need satisfaction is also found to mediate the relationship between followers' use of own emotions and job performance. In addition, follower job performance is found to be directly related to followers' use of emotions. Hence, to attain desirable follower outcomes, we recommend that one should not only consider a leader's use of emotions but also followers' use of their own emotions (Isen and Reeve, 2005; Sy and Choi, 2013).

This study contributes to the SDT by showing that an employee's experience of selfdetermination, as measured by psychological need satisfaction, is related to and probably stimulated by a constructive use of emotions by both the leader and the employee him- $/$ herself (Isen and Reeve, 2005). Hence, we suggest that followers' sense of autonomy, competence and relatedness increases when their leader and/or they themselves make constructive use of their own emotions. Prior research had already established that a high level of self-determination is a predictor of high job performance. The currently reported evidence shows how psychological need satisfaction is associated with job performance. Two conditions for increasing followers' sense of self-determination and, through that, their level of job performance are making constructive use of own emotions at work, and the 
perception that their leader does the same. In fact, the results of this study point to the probable existence of two affective antecedent factors in employee motivation for high performance; we thereby illustrate that the SDT is an extensible framework.

Given the hierarchical relations between a leader and followers, we could interpret this study's results as an indication of the performative power of emotional expressive leadership (Ilies et al., 2013). Moreover, it is likely that the more a leader is seen by his or her followers as using his or her emotions at work, the more the followers will do the same, because there is evidence of mimicry in leader-follower relationships (Menges et al., 2015; Hale et al., 2020). In other words, our results suggest that when a leader is seen by followers as making good use of his or her emotions, a condition is created for the followers to make good use of their own emotions at work (Table 2, $r=0.16, p<0.01$ ) and, when they do, they thrive and perform well. The extent to which reciprocal effects occur between a leader's use of emotions and his or her followers' use of emotions should also be explored. Such future research is likely to reinforce and refine the empirical fact that follower reactions to leaders' expressions of positive and negative emotions are linked to follower job performance (Gooty et al., 2010; Silard and Dasborough, 2021). So far, prior studies have provided little insight into the precise affective mechanisms by which leaders motivate their followers (Yukl, 1998). Eberly and Fong (2013) found that leaders who express positive emotions are considered to be more effective by followers than those who express negative emotions (Richard, 2020). More of such investigations are encouraged, also in connection with how the other El dimensions affect both leaders and their followers, including the role of "emotional contagion." In addition to the SDT, it is likely that the social information processing theory can explain how followers process socio-emotional and related selfemotion-based information better from their job-based experiences, which they may use to "reframe" or "steer" levels of personal confidence and effort in performing their jobs. Hence, more studies are recommended that blend social-cognitive theorizing with the performative effects of followers' socio-emotional work experiences. More specifically, fine-grained observations of the whole range of emotions that may play a role in the working lives of both leaders and followers, and the ways in which they hide or express them to each other, as well as their effects, would be fruitful focal points in new studies.

In the context of the emerging theory of followership (Uhl-Bien et al., 2014), the current study evinces that when a follower is able to use his or her emotions constructively, he or she is more likely to show high job performance. For example, a nurse who serves patients and others well is likely to make good use of his/her own emotions (Reebals et al., 2021). A leader's good use of emotions at work does not seem to contribute directly to his or her followers' job performance, but rather indirectly through a high degree of follower psychological need satisfaction. Thus, the effects of leader-follower relationships on important positive or negative follower outcomes depend on the emotional connections involved (Leheta et al., 2017; Silard and Dasborough, 2021; Yagil and Medler-Liraz, 2014).

\section{Practical implications}

The findings of this study provide several important insights for practice. Perhaps most remarkable is our evidence of how key employee outcomes are significantly related to their leader's use of emotions. If leaders use their own emotions constructively, they are more likely to increase their followers' degree of psychological need satisfaction, which in turn can improve follower job performance. Thus, leaders must be made aware of the fact that obtaining high follower job performance can also be achieved indirectly through their own use of emotions, and not just through task-based (transactional) exchanges or merely focusing on productive results (Niven et al., 2019).

Leaders' emotional effects on follower performance should not be exaggerated because follower use of own emotions appears to have both a direct and indirect effect on follower job performance. Human resource management units in organizations may need to 
highlight these intricate follower performance predictors to (some of) their leaders or at least advocate them to take followers' use of their own emotions also more seriously given the likely beneficial effects on followers' job performance (Kotsou et al., 2011).

It may also be necessary to make followers aware of the fact that, to achieve high job performance, it would be good to be proficient in managing their own emotions at work. This is based on our results suggesting that followers' constructive use of their own emotions will not only affect their own job performance, but also their personal level of psychological need satisfaction. Given the effects of emotional contagion in work units (Barsade, 2002), these units are more likely to benefit from an improved human skill level when organizational leaders take employees' emotional skills more seriously (Wilderom et al., 2015), ideally even already during their recruiting/selection efforts. In conclusion, our study suggests that when both leaders and followers become better at using their own emotions constructively, they will improve many stakeholders' quality of life (Reebals et al., 2021).

\section{Strengths, limitations and future research}

Clearly, much more research is needed on how leaders' expressed emotions affect followers' motivation and performance (Silard and Dasborough, 2021). It is imperative for such efforts to extend the SDT to the innate emotional relationships between leaders and followers. To substantiate the versatility of SDT, the present study examines how both followers' use of their own emotions and their leader's use of own emotions affect followers' job performance. Given the perceptual nature of the concepts, it is correct to assume that the self-report-type strategy on emotion and psychological need satisfaction used here is appropriate (Dasborough and Ashkanasy, 2002; Gerstner and Day, 1997; Martinko and Gardner, 1987).

As the followers in this study provided the data for each of the variables themselves, the study is not free from common method variance, although we avoided identical lead questions when using each of the scales (Podsakoff et al., 2003). Harman's single-factor test suggests that the effect of common method variance was not a major problem here (Fisk and Friesen, 2012), and the use of a common latent factor did correct for common-rater bias between the constructs of the structural model. In addition, because the study was cross-sectional in design, the results may not work exactly according to the implied underlying one-directional causal framework. We, therefore, propose to conduct longitudinal investigations in the future; ideally in a different, less professional sector than nursing, and even outside Asia. Furthermore, it should be noted that the variable "use of emotions by leaders" is an indirect, follower-based measure. This is sufficient for our research into its relationships with follower job motivation and performance, but future research may need to obtain "leader-use-of-emotions" data from groups of followers who share the same leader. Such future research should separate the collection of predictor and criterion data across time and raters through, e.g. daily diary research or multi-source longitudinal and quasi-experimental designs (Philippe and Vallerand, 2008). At the same time, it would be valuable to examine the three other aforementioned El dimensions. This would complement other studies of emotion and El at work and could show us better why and how sharpening employee's overall El is a key to both psychological need satisfaction and higher job performance.

From a theoretical and training perspective, future research should also investigate more factors that may play a role. Whereas the use of emotions concept focuses on how employees use their emotions constructively to improve their job performance, studies on emotion regulation emphasize the use of emotions to deal with psychological distress (Wong and Law, 2002). Thus, it would also be fruitful to examine further how followers use their own and others' emotions to regulate their negative emotions to achieve desirable job outcomes. Furthermore, it would be relevant to investigate how leaders, who are highly skilled at using their own emotions, deal with followers who struggle with using their own emotions. Those leaders may be able to help such followers by explicitly "mentoring" or "coaching" them to satisfy their three key intrinsic needs and thereby become higher 
performers. All in all, investigating the relationships between follower and leader El, their emotions, psychological need satisfaction and work outcomes is clearly a line of research that warrants many more fascinating studies. While most of the literature on emotions at work (including El) focuses on leaders' abilities to process and display emotions at work (Little et al., 2016), the present study deals with followers' perceptions of their leader's use of emotions vis-à-vis their own use of emotions at work. Even though a leader's constructive use of emotions is shown to play an indirect job performative role, through a higher level of follower satisfaction of basic psychological needs, it appears that a follower's own constructive use of emotions plays a direct job performative role.

\section{References}

Alam, A. and Ahmad, M. (2018), "The role of teachers' emotional intelligence in enhancing student achievement”, Journal of Asia Business Studies, Vol. 12 No. 1, pp. 31-43.

Anderson, J.C. and Gerbing, D.W. (1991), "Predicting the performance of measures in a confirmatory factor analysis with a pretest assessment of their substantive validities", Journal of Applied Psychology, Vol. 76 No. 5, pp. 732-740.

Antonakis, J., Ashkanasy, N.M. and Dasborough, M.T. (2009), "Does leadership need emotional intelligence?", The Leadership Quarterly, Vol. 2, pp. 247-261.

Ashkanasy, N.M. and Humphrey, R.H. (2011), "Current emotion research in organizational behavior", Emotion Review, Vol. 3 No. 2, pp. 214-224.

Ashkanasy, N.M., Humphrey, R.H. and Huy, Q.N. (2017), "Integrating emotions and affect in theories of management", Academy of Management Review, Vol. 42 No. 2, pp. 175-189.

Baard, P.P., Deci, E.L. and Ryan, R.M. (2004), "Intrinsic need satisfaction: a motivational basis of performance and well-being in two work settings", Journal of Applied Social Psychology, Vol. 34 No. 10, pp. 2045-2068.

Baron, R.M. and Kenny, D.A. (1986), "The moderator-mediator variable distinction in social psychological research: conceptual, strategic, and statistical considerations", Journal of Personality and Social Psychology, Vol. 51 No. 6, pp. 1173-1182.

Barsade, S.G. (2002), "The ripple effect: emotional contagion and its influence on group behavior", Administrative Science Quarterly, Vol. 47 No. 4, pp. 644-675.

Barsade, S.G., Ward, A.J., Turner, J.D.F. and Sonnenfeld, J.A. (2000), "To your heart's content: a model of affective diversity in top management teams", Administrative Science Quarterly, Vol. 45 No. 4, pp. 802-836.

Bauer, T.N. and Green, S.G. (1996), "Development of leader-member exchange: a longitudinal test", Academy of Management Journal, Vol. 39, pp. 1538-1567.

Benita, M., Levkovitz, T. and Roth, G. (2017), "Integrative emotion regulation predicts adolescents' prosocial behavior through the mediation of empathy", Learning and Instruction, Vol. 50, pp. 14-20.

Benita, M., Benish-Weisman, M., Matos, L. and Torres, C. (2020), "Integrative and suppressive emotion regulation differentially predict well-being through basic need satisfaction and frustration: a test of three countries", Motivation and Emotion, Vol. 44 No. 1, pp. 67-81.

Busari, A.H., Khan, S.N., Abdullah, S.M. and Mughal, Y.H. (2019), "Transformational leadership style, followership, and factors of employees' reactions towards organizational change", Journal of Asia Business Studies, Vol. 14 No. 2, pp. 181-209.

Cerasoli, C.P., Nicklin, J.M. and Nassrelgrgawi, A.S. (2016), "Performance, incentives, and needs for autonomy, competence, and relatedness: a Meta-analysis", Motivation and Emotion, Vol. 40 No. 6, pp. 781-813.

Chiniara, M. and Bentein, K. (2016), "Linking servant leadership to individual performance: differentiating the mediating role of autonomy, competence and relatedness need satisfaction", The Leadership Quarterly, Vol. 27 No. 1, pp. 124-141.

Connelly, S. and Ruark, G. (2010), "Leadership style and activating potential moderators of the relationships among leader emotional displays and outcomes", The Leadership Quarterly, Vol. 21 No. 5, pp. 745-764. 
Damen, F., Van Knippenberg, B. and Van Knippenberg, D. (2008), "Affective match in leadership: leader emotional displays, follower positive affect, and follower performance", Journal of Applied Social Psychology, Vol. 38 No. 4, pp. 868-902.

Dasborough, M.T. (2006), "Cognitive asymmetry in employee emotional reactions to leadership behaviors", The Leadership Quarterly, Vol. 17 No. 2, pp. 163-178.

Dasborough, M.T. and Ashkanasy, N.M. (2002), "Emotion and attribution of intentionality", The Leadership Quarterly, Vol. 13 No. 5, pp. 615-634.

De Melo, C.M., Carnevale, P.J., Read, S.J. and Gratch, J. (2014), "Reading people's minds from emotion expressions in interdependent decision making", Journal of Personality and Social Psychology, Vol. 106 No. 1, pp. 73-88.

Deci, E.L. and Ryan, R.M. (1985), Intrinsic Motivation and Self-Determination in Human Behavior, Plenum Press, New York, NY.

Deci, E.L. and Ryan, R.M. (2000), "The 'what' and 'why' of goal pursuits: human needs and the selfdetermination of behavior", Psychological Inquiry, Vol. 11 No. 4, pp. 227-268.

Deci, E.L., Ryan, R.M., Gagne, M., Leone, D.R., Usunov, J. and Kornazheva, B.P. (2001), "Need satisfaction, motivation, and well-being in the work organizations of a former Eastern bloc country: a cross-cultural study of self-determination", Personality and Social Psychology Bulletin, Vol. 27 No. 8, pp. 930-942.

Eberly, M.B. and Fong, C.T. (2013), "Leading via the heart and mind: the roles of leader and follower emotions, attributions and interdependence", The Leadership Quarterly, Vol. 24 No. 5, pp. 696-711.

Engelen, A., Gupta, V., Strenger, L. and Brettel, M. (2015), "Entrepreneurial orientation, firm performance, and the moderating role of transformational leadership behaviors", Journal of Management, Vol. 41 No. 4, pp. 1069-1097.

Extremera, N., Mérida-López, S., Sánchez-Álvarez, N. and Quintana-Orts, C. (2018), "How does emotional intelligence make one feel better at work? The mediational role of work engagement", International Journal of Environmental Research and Public Health, Vol. 15 No. 9, p. 1909.

Fisk, G.M. and Friesen, J.P. (2012), "Perceptions of leader emotion regulation and LMX as predictors of followers' job satisfaction and organizational citizenship behaviors", The Leadership Quarterly, Vol. 23 No. 1, pp. 1-12.

Fredrickson, B.L. (2001), "The role of positive emotions in positive psychology. The", American Psychologist, Vol. 56 No. 3, pp. 218-226.

Fredrickson, B.L. and Losada, M.F. (2005), "Positive affect and the complex dynamics of human flourishing", American Psychologist, Vol. 60 No. 7, pp. 678-686.

Gagne, M. (2003), "Autonomy support and need satisfaction in the motivation and well-being of gymnasts", Journal of Applied Sport Psychology, Vol. 15 No. 4, pp. 372-390.

Gagne, M. and Deci, E.L. (2005), "Self-determination theory and work motivation", Journal of Organizational Behavior, Vol. 26 No. 4, pp. 331-362.

Gasper, K. and Clore, G.L. (2000), "Do you have to pay attention to your feelings to be influenced by them?", Personality and Social Psychology Bulletin, Vol. 26 No. 6, pp. 698-711.

Gerstner, C.R. and Day, D.V. (1997), "Meta-analytic review of leader-member exchange theory: correlates and construct issues", Journal of Applied Psychology, Vol. 82 No. 6, pp. 827-844.

Gillet, N., Fouquereau, E., Forest, J., Brunault, P. and Colombat, P. (2012), "The impact of organizational factors on psychological needs and their relations with well-being", Journal of Business and Psychology, Vol. 27 No. 4, pp. 437-450.

Gómez-Baya, D., Lucia-Casademunt, A.M. and Salinas-Pérez, J.A. (2018), "Gender differences in psychological well-being and health problems among European health professionals: analysis of psychological basic needs and job satisfaction", International Journal of Environmental Research and Public Health, Vol. 15 No. 7, p. 1474.

Gooty, J., Connelly, S., Griffith, J. and Gupta, A. (2010), "Leadership, affect and emotions: a state of the science review", The Leadership Quarterly, Vol. 21 No. 6, pp. 979-1004.

Haivas, S., Hofmans, J. and Pepermans, R. (2012), "Self-determination theory as a framework for exploring the impact of the organizational context on volunteer motivation: a study of Romanian volunteers", Nonprofit and Voluntary Sector Quarterly, Vol. 41 No. 6, pp. 1195-1214. 
Hale, J., Ward, J.A., Buccheri, F., Oliver, D. and Hamilton, A.F.D.C. (2020), "Are you on my wavelength? Interpersonal coordination in dyadic conversations”, Journal of Nonverbal Behavior, Vol. 44 No. 1, pp. 63-83.

Harman, H.H. (1976), Modern Factor Analysis, University of Chicago Press, Chicago.

Hatfield, E., Cacioppo, J. and Rapson, R. (1994), Emotional Contagion, Cambridge University Press, Cambridge.

Haver, A., Akerjordet, K. and Furunes, T. (2013), "Emotion regulation and its implications for leadership", Journal of Leadership \& Organizational Studies, Vol. 20 No. 3, pp. 287-303.

Hu, L.T. and Bentler, P.M. (1999), "Cutoff criteria for fit indexes in covariance structure analysis: conventional criteria versus new alternatives", Structural Equation Modeling: A Multidisciplinary Journal, Vol. 6 No. 1, pp. 1-55.

Huang, H., Liu, L., Yang, S., Cui, X., Zhang, J. and Wu, H. (2019), "Effects of job conditions, occupational stress, and emotional intelligence on chronic fatigue among Chinese nurses: a cross-sectional study", Psychology Research and Behavior Management, Vol. Volume 12, pp. 351-360.

Ilies, R., Curşeu, P.L., Dimotakis, N. and Spitzmuller, M. (2013), "Leaders' emotional expressiveness and their behavioural and relational authenticity: effects on followers", European Journal of Work and Organizational Psychology, Vol. 22 No. 1, pp. 4-14.

Isen, A.M. and Reeve, J. (2005), "The influence of positive affect on intrinsic and extrinsic motivation: facilitating enjoyment of play, responsible work behavior, and self-control", Motivation and Emotion, Vol. 29 No. 4, pp. 297-325.

Jõesaar, H., Hein, V. and Hagger, M.S. (2012), "Youth athletes' perception of autonomy support from the coach, peer motivational climate and intrinsic motivation in sport setting: one-year effects", Psychology of Sport and Exercise, Vol. 13 No. 3, pp. 257-262.

Kelly, J.R. and Barsade, S.G. (2001), "Mood and emotions in small groups and work teams", Organizational Behavior and Human Decision Processes, Vol. 86 No. 1, pp. 99-130.

Kotsou, I., Nelis, D., Grégoire, J. and Mikolajczak, M. (2011), "Emotional plasticity: conditions and effects of improving emotional competence in adulthood", Journal of Applied Psychology, Vol. 96 No. 4, pp. 827-839.

Kovjanic, S., Schuh, S.C., Jonas, K., Quaquebeke, N.V. and Van Dick, R. (2012), "How do transformational leaders foster positive employee outcomes? A self-determination-based analysis of employees' needs as mediating links", Journal of Organizational Behavior, Vol. 33 No. 8, pp. 1031-1052.

Kraiger, K., Billings, R.S. and Isen, A.M. (1989), "The influence of positive affective states on task perceptions and satisfaction", Organizational Behavior and Human Decision Processes, Vol. 44 No. 1, pp. 12-25.

Kumar, P. (2019), "The impact of patient recovery flexibility on service experience in public healthcare", Journal of Asia Business Studies, Vol. 14 No. 2, pp. 159-179.

Law, K.S., Wong, C.-S. and Song, L.J. (2004), "The construct and criterion validity of emotional intelligence and its potential utility for management studies", Journal of Applied Psychology, Vol. 89 No. 3, pp. 483-496.

Law, K.S., Wong, C.-S., Emily Huang, G. and Li, X. (2008), "The effects of emotional intelligence on job performance and life satisfaction for the research and development scientists in China", Asia Pacific Journal of Management, Vol. 251, pp. 51-69.

Leheta, D., Dimotakis, N. and Schatten, J. (2017), "The view over one's shoulder: the causes and consequences of leader's envy of followers", The Leadership Quarterly, Vol. 28 No. 3, pp. 451-468.

Leroy, H., Anseel, F., Gardner, W.L. and Sels, L. (2015), "Authentic leadership, authentic followership, basic need satisfaction, and work role performance", Journal of Management, Vol. 41 No. 6, pp. 1677-1697.

Little, L.M., Gooty, J. and Williams, M. (2016), "The role of leader emotion management in leader-member exchange and follower outcomes”, The Leadership Quarterly, Vol. 27 No. 1, pp. 85-97.

Martinko, M.J. and Gardner, W.L. (1987), "The leader/member attribution process", Academy of Management Review, Vol. 12 No. 2, pp. 235-249.

Mathieu, J.E. and Taylor, S.R. (2006), "Clarifying conditions and decision points for mediational type inferences in organizational behavior", Journal of Organizational Behavior, Vol. 27 No. 8, pp. 1031-1056.

Mayer, J.D. and Salovey, P. (1997), "What is emotional intelligence? ", In Emotional Development and Emotional Intelligence: Implications for Educators, Basic Books, New York, NY, pp. 3-31.

Mayer, J.D., Roberts, R.D. and Barsade, S.G. (2008), "Human abilities: emotional intelligence", Annual Review of Psychology, Vol. 59 No. 1, pp. 507-536. 
Menges, J.I., Kilduff, M., Kern, S. and Bruch, H. (2015), "The awestruck effect: followers suppress emotion expression in response to charismatic but not individually considerate leadership", The Leadership Quarterly, Vol. 26 No. 4, pp. 626-640.

Montano, D., Reeske, A., Franke, F. and Hüffmeier, J. (2017), "Leadership, followers' mental health and job performance in organizations: a comprehensive Meta-analysis from an occupational health perspective", Journal of Organizational Behavior, Vol. 38 No. 3, pp. 327-350.

Newcombe, M. and Ashkanasy, N.M. (2002), "The role of affect and affective congruence in perceptions of leaders: an experimental study”, The Leadership Quarterly, Vol. 13 No. 5, pp. 601-614.

Niven, K., Troth, A.C. and Holman, D. (2019), "Do the effects of interpersonal emotion regulation depend on people's underlying motives?", Journal of Occupational and Organizational Psychology, Vol. 92 No. 4, pp. 1020-1026.

Pattnaik, S.C. and Panda, N. (2020), "Supervisor support, work engagement and turnover intentions: evidence from Indian call centres", Journal of Asia Business Studies, Vol. 14 No. 5, pp. 621-635.

Petty, R.E. and Briñol, P. (2015), "Emotion and persuasion: cognitive and Meta-cognitive processes impact attitudes", Cognition and Emotion, Vol. 29 No. 1, pp. 1-26.

Philippe, F.L. and Vallerand, R.J. (2008), "Actual environments do affect motivation and psychological adjustment: a test of self-determination theory in a natural setting", Motivation and Emotion, Vol. 32 No. 2 , pp. 81-89.

Podsakoff, P.M., MacKenzie, S.B., Lee, J.-Y. and Podsakoff, N.P. (2003), "Common method biases in behavioral research: a critical review of the literature and recommended remedies", Journal of Applied Psychology, Vol. 88 No. 5, pp. 879-903.

Reebals, C., Wood, T. and Markaki, A. (2021), "Transition to practice for new nurse graduates: barriers and mitigating strategies", Western Journal of Nursing Research (in Press).

Richard, E.M. (2020), "Developing employee resilience: the role of leader-facilitated emotion management", Advances in Developing Human Resources, Vol. 22 No. 4, pp. 387-403.

Roth, G., Shahar, B.H., Zohar-Shefer, Y., Benita, M., Moed, A., Bibi, U. and Ryan, R.M. (2018), "Benefits of emotional integration and costs of emotional distancing", Journal of Personality, Vol. 86 No. 6, pp. 919-934.

Ryan, R.M. and Deci, E.L. (2000), "Self-determination theory and the facilitation of intrinsic motivation, social development, and well-being", American Psychologist, Vol. 55 No. 1, pp. 68-78.

Salovey, P. and Mayer, J.D. (1990), "Emotional intelligence", Imagination, Cognition, and Personality, Vol. 9 No. 3, pp. 185-211.

Shamir, B., House, R.J. and Arthur, M.B. (1993), "The motivational effects of charismatic leadership: a self-concept based theory", Organization Science, Vol. 4 No. 4, pp. 577-594

Shi, J. and Wang, L. (2007), "Validation of emotional intelligence scale in Chinese university students", Personality and Individual Differences, Vol. 43 No. 2, pp. 377-387.

Silard, A. and Dasborough, M.T. (2021), "Beyond emotion valence and arousal: a new focus on the target of leader emotion expression within leader-member dyads", Journal of Organizational Behavior.

Spering, M., Wagener, D. and Funke, J. (2005), "The role of emotions in complex problem solving", Cognition \& Emotion, Vol. 19 No. 8, pp. 1252-1261.

Suharnomo, S. and Hashim, F. (2019), "Differences in organization citizenship behavior between 'serumpun' countries (Indonesia-Malaysia)", Journal of Asia Business Studies, Vol. 13 No. 3, pp. 349-361.

Sy, T. and Choi, J.N. (2013), "Contagious leaders and followers: exploring multi-stage mood contagion in a leader activation and member propagation (LAMP) model", Organizational Behavior and Human Decision Processes, Vol. 122 No. 2, pp. 127-140.

Sy, T., Côté, S. and Saavedra, R. (2005), "The contagious leader: impact of the leader's mood on the mood of group members, group affective tone, and group processes", Journal of Applied Psychology, Vol. 90 No. 2, pp. 295-305.

Sy, T., Horton, C. and Riggio, R. (2018), "Charismatic leadership: eliciting and channeling follower emotions", The Leadership Quarterly, Vol. 29 No. 1, pp. 58-69.

Tugade, M.M. and Fredrickson, B.L. (2007), "Regulation of positive emotions: emotion regulation strategies that promote resilience", Journal of Happiness Studies, Vol. 8 No. 3, pp. 311-333. 
Uhl-Bien, M., Riggio, R.E., Lowe, K.B. and Carsten, M.K. (2014), "Followership theory: a review and research agenda", The Leadership Quarterly, Vol. 25 No. 1, pp. 83-104.

Van den Broeck, A., Vansteenkiste, M., De Witte, H. and Lens, W. (2008), "Explaining the relationships between job characteristics, burnout, and engagement: the role of basic psychological need satisfaction", Work \& Stress, Vol. 22 No. 3, pp. 277-294.

Van Doorn, E.A., van Kleef, G.A. and van der Pligt, J. (2015), "Deriving meaning from others' emotions: attribution, appraisal, and the use of emotions as social information", Frontiers in Psychology, Vol. 6, p. 1077.

Van Kleef, G.A. (2009), "How emotions regulate social life: the emotions as social information (EASI) model", Current Directions in Psychological Science, Vol. 18 No. 3, pp. 184-188.

Van Kleef, G.A., De Dreu, C.K.W. and Manstead, A.S.R. (2010), "An interpersonal approach to emotion in social decision making: the emotions as social information model”, in Zanna, M.P. (Ed.), Advances in Experimental Social Psychology, Academic Press, San Diego, CA, Vol. 42, pp. 45-96.

Van Kleef, G.A., Van Doorn, E.A., Heerdink, M.W. and Koning, L.F. (2011), "Emotion is for influence", European Review of Social Psychology, Vol. 22 No. 1, pp. 114-163.

Van Knippenberg, D., Van Knippenberg, B., Van Kleef, G. and Damen, F. (2008), "Leadership, affect, and emotions", in Ashkanasy, N.M. and Cooper, C. (Eds), Research Companion to Emotions in Organizations, Edward Elgar, Cheltenham, pp. 465-475.

Vandercammen, L., Hofmans, J. and Theuns, P. (2014a), "The mediating role of affect in the relationship between need satisfaction and autonomous motivation", Journal of Occupational and Organizational Psychology, Vol. 87 No. 1, pp. 62-79.

Vandercammen, L., Hofmans, J. and Theuns, P. (2014b), "Relating specific emotions to intrinsic motivation: on the moderating role of positive and negative emotion differentiation", PLOS ONE, Vol. 9 No. 12, pp. 1-22.

Venus, M., Stam, D. and Van Knippenberg, D. (2013), "Leader emotion as a catalyst of effective leader communication of visions, value-laden messages, and goals", Organizational Behavior and Human Decision Processes, Vol. 122 No. 1, pp. 53-68.

Verleysen, B., Lambrechts, F. and Van Acker, F. (2014), "Building psychological capital with appreciative inquiry: investigating the mediating role of basic psychological need satisfaction", The Journal of Applied Behavioral Science, Vol. 26, pp. 1-26.

Wilderom, C.P.M., Hur, Y., Wiersma, U.J., Van den Berg, P.T. and Lee, J. (2015), "From manager's emotional intelligence to objective store performance: through store cohesiveness and sales-directed employee behavior", Journal of Organizational Behavior, Vol. 36 No. 6, pp. 825-844.

Williams, L.J. and Anderson, S.E. (1991), "Job satisfaction and organizational commitment as predictors of organizational citizenship and in-role behaviors”, Journal of Management, Vol. 17 No. 3, pp. 601-617.

Wong, C.-S. and Law, K.S. (2002), "The effects of leader and follower emotional intelligence on performance and attitude: an exploratory study", The Leadership Quarterly, Vol. 13 No. 3, pp. 243-274.

Yagil, D. and Medler-Liraz, H. (2014), "Feel free, be yourself: authentic leadership, emotional expression, and employee authenticity”, Journal of Leadership \& Organizational Studies, Vol. 21 No. 1, pp. 59-70.

Yukl, G. (1998), Leadership in Organizations, Prentice-Hall, Englewood, Cliffs, NJ.

\section{Further reading}

Dóci, E. and Hofmans, J. (2015), "Task complexity and transformational leadership: the mediating role of leaders' state core self-evaluations", The Leadership Quarterly, Vol. 26 No. 3, pp. 436-447.

\section{Corresponding author}

Sunu Widianto can be contacted at: sunu.widianto@unpad.ac.id

For instructions on how to order reprints of this article, please visit our website: www.emeraldgrouppublishing.com/licensing/reprints.htm

Or contact us for further details: permissions@emeraldinsight.com 